\title{
Long-Term Variability and Trends in the Caribbean Sea
}

\author{
Mark R. Jury ${ }^{1,2}$ \\ ${ }^{1}$ Department of Physics, University of Puerto Rico at Mayagüez, Mayagüez 00681, Puerto Rico
}

${ }^{2}$ University of Zululand, KwaDlangezwa 3886, South Africa

Correspondence should be addressed to Mark R. Jury, mark.jury@upr.edu

Received 30 September 2010; Revised 22 December 2010; Accepted 8 January 2011

Academic Editor: William Hsieh

Copyright (C 2011 Mark R. Jury. This is an open access article distributed under the Creative Commons Attribution License, which permits unrestricted use, distribution, and reproduction in any medium, provided the original work is properly cited.

\begin{abstract}
Upper ocean conditions in the Caribbean Sea are studied for long-term variability and trends using filtered surface observations and ocean model reanalysis fields. A principal component analysis is made, and trends in the leading mode are extracted. Sea surface temperature shows an accelerating upward trend while air pressure exhibits quasidecadal fluctuations. Sea surface height and subsurface temperature rise linearly while subsurface salinity exhibits fresher upper and saltier lower layers. The amplitude of warming is highest in the southern Caribbean east of $75^{\circ} \mathrm{W}$ near $150 \mathrm{~m}$ and lowest near the surface, indicating little role for a top-down process such as air-sea exchange. The freshening surface layer does not appear connected to river discharge or regional rainfall, so changes in ocean advection and sources are the likely drivers. Westward currents exhibit a reduction of throughflow and an influx from the Windward Passage. The Caribbean Current has slowed $\sim 0.06 \mathrm{~m} / \mathrm{s}$ in the reanalysis era. Crop yields show little sensitivity to ocean conditions but tend to follow rainfall. Marine catch per capita in the Caribbean follows subsurface currents and vertical motion but is less affected by temperature and salinity.
\end{abstract}

\section{Introduction}

The accumulation of greenhouse gases and consequent absorption of radiation has resulted in an atmospheric warming that is faster in the Caribbean than elsewhere in the tropics. This is related to a local acceleration of the Hadley cell and gas plumes that drift west from Africa [1], producing a drying trend that is projected to continue in the 21 st century [2]. How the sub-surface ocean contributes to global warming has recently been explored using observed temperature profiles and ocean model projections [3]. Across the central Antilles, the rate of warming at the top of the atmospheric boundary layer is triple the ocean surface, so sensible heat fluxes are declining. This has implications for the thermodynamic energy available to tropical weather systems within the region [4] and to the advection of heat, moisture and momentum out of the region.

The Caribbean Sea is bounded on the south and west by South and Central America, and fringed on the east and north by the chain of Antilles Islands $\left(8^{\circ} \mathrm{N}-25^{\circ} \mathrm{N}, 85^{\circ} \mathrm{W}-55^{\circ} \mathrm{W}\right)$ and Atlantic Ocean. Persistent subtropical trade winds, year-round sunshine, and consistent water exchanges result in little seasonal variation. The surface warm layer is $>100 \mathrm{~m}$ deep and the upper $1200 \mathrm{~m}$ is stratified $[5,6]$. Most Atlantic water infiltrates the Caribbean Sea through the Grenada, St. Vincent, and St. Lucia Passages in the southeast $[7,8]$ sourced from the meandering North Brazil Current that bears fresh water from the Orinoco River. From there, the Caribbean Current flows westward at $0.5 \mathrm{~m} / \mathrm{s}$ in the latitudes $13-16^{\circ} \mathrm{N}$ [9-11]. It turns northwest between Nicaragua and Jamaica, with a branch forming the counterclockwise Panama Gyre $[8,12,13]$. Westward currents exit via the Yucatan Channel eventually to be drawn into the Gulf Stream, which receives contributions from the Antilles Current and its Atlantic sources [14, 15]. Schmitz and Richardson [16] and Johns et al. [7] indicate that the Caribbean Sea is well ventilated with $\sim 28 \mathrm{~Sv}$ of throughflow from both the North and the South Atlantic [17, 18]. South Atlantic waters are fresher and more oxygenated than North Atlantic waters of the same density, they enter the Caribbean near Trinidad. While the mean structure of water masses and currents in the Caribbean is well known and processes underlying year-to-year fluctuations are being uncovered [19], long-term trends and influences are relatively unexplored. 


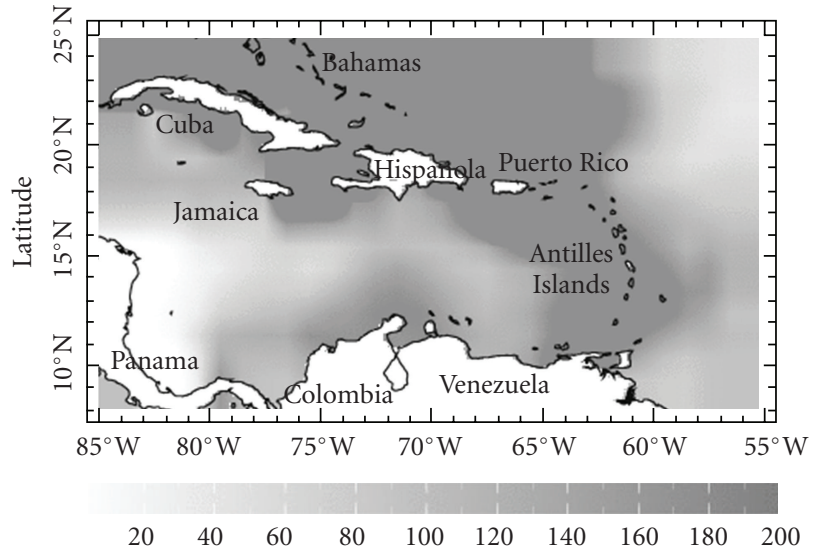

(a)

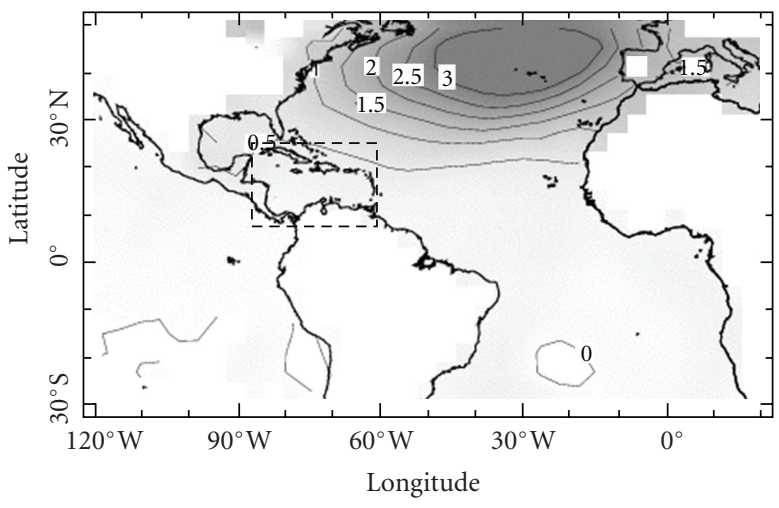

(c)

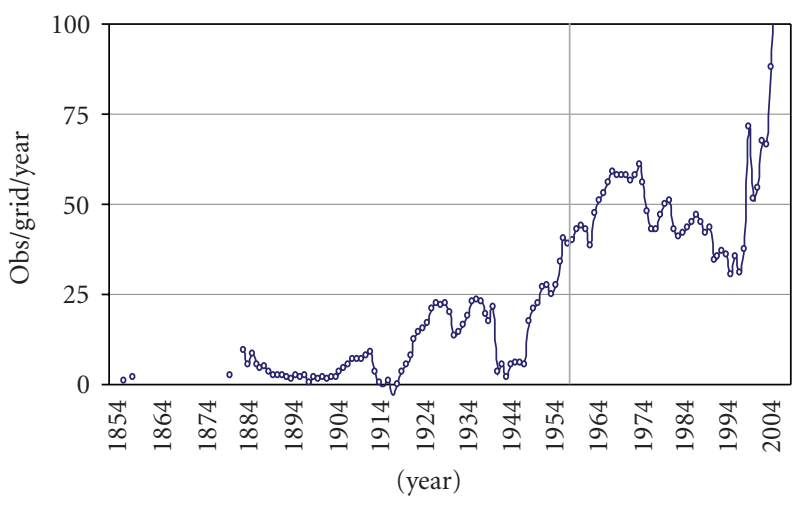

(b)

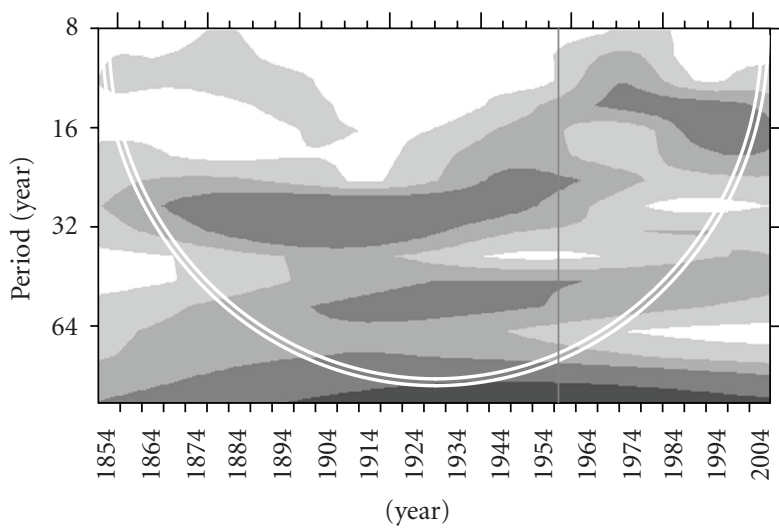

(d)

Figure 1: (a) Density of temperature observations per grid cell averaged 1-300 m depth over 1958-2007 and place names. (b) Time series of sea temperature observations averaged over the Caribbean. Starting point for sub-surface analysis is vertical line. (c) Spatial pattern of SLP mode-1 pattern (1854-2007) as an indication of multidecadal amplitude. (d) Wavelet cospectra of Caribbean SLP and SST (cf. Figures 2(a) and 2 (b)), with power contoured at intervals $10,25,50,75 \%$, and cone of validity.

Here, long-term variability and trends in the upper ocean across the Caribbean are described in terms of spatial pattern and temporal amplitude. Some of the processes underlying the trends and their biophysical consequences are studied. The key question is how is the global warming signal reflected in the Caribbean Sea? The hypothesis is that the response is top-down (greatest trend near the surface) and spatially homogeneous.

\section{Data and Methods}

Long-term trends at the ocean surface are characterized by ship and satellite data reanalyzed by the National Ocean and Atmosphere Administration (NOAA) for sea surface temperatures (SST; see [20]) and by the National Center for Environmental Prediction (NCEP) for wind [21, 22]. Sea level pressure (SLP) derives from ship data reanalysis by the Hadley Center [23], and tropical cyclone prevalence is from Emanuel [24]. Data were gathered from the Climate Explorer http://climexp.knmi.nl/ and Climate Library http://iridl.ldeo.columbia.edu/ websites over the period since 1854. Surface data are averaged over the
Caribbean $\left(8^{\circ} \mathrm{N}-25^{\circ} \mathrm{N}, 85^{\circ} \mathrm{W}-55^{\circ} \mathrm{W} ; \sim 610^{6} \mathrm{~km}^{2}\right)$, where observations are relatively dense, except north of Panama (Figure 1(a)). This domain cuts off the Gulf of Mexico and Straits of Florida. Over time, ship reports of sub-surface temperature vary from near zero before 1880 to $>20 / 1^{\circ}$ cell/year after 1925 (Figure 1(b)). Recent years have seen a sharp upturn with profiling floats.

Upper ocean conditions are described, since 1958, by Simple Ocean Data Assimilation (SODA) fields version 2.4 [25] comprising sea surface height (SSH), temperature $(T)$, salinity $(S)$, currents $(U, V)$, and vertical motion $(W)$ at $50 \mathrm{~km}$ horizontal and $\sim 50 \mathrm{~m}$ vertical resolution. Surface wind stress $(\tau X, \tau Y)$ is derived from European Community Medium-range Weather Forecasts (ECMWF; see [26]). The ocean fields are based on a numerical model assimilation of in situ and remotely sensed data, and include coastal station and ship hydrographic data; satellite surface temperature, altimetric height, and winds; ocean drifters and profiling floats, ingested by the Global Ocean Data Assimilation System and its predecessors. Although the Caribbean has reasonable coverage for surface elements and ocean profiles in the reanalysis era (Figure $1(\mathrm{~b})$ ), it is useful to minimize 


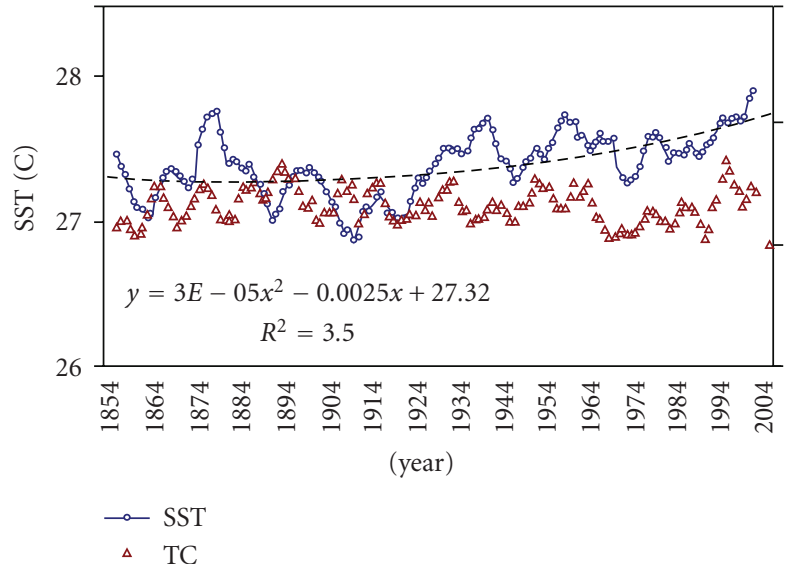

(a)

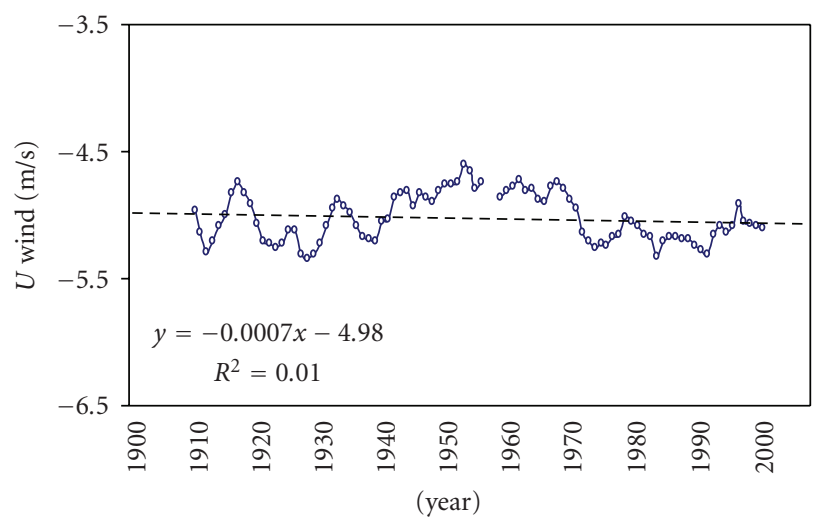

(c)

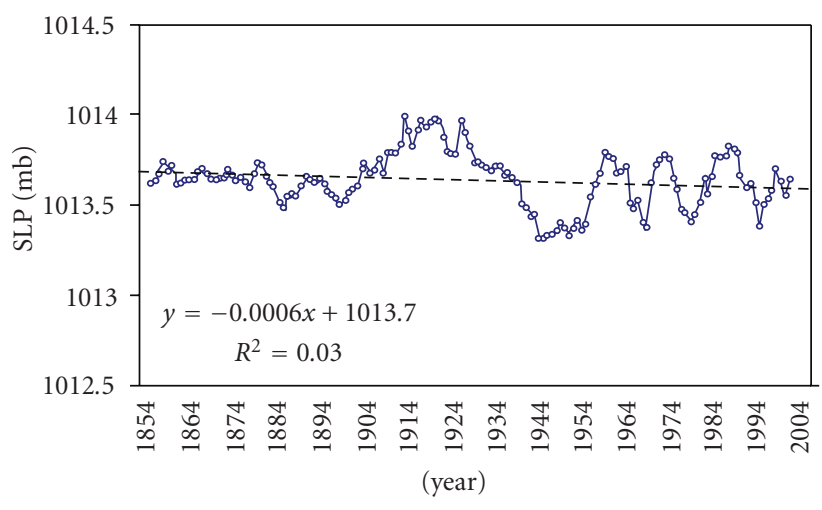

(b)

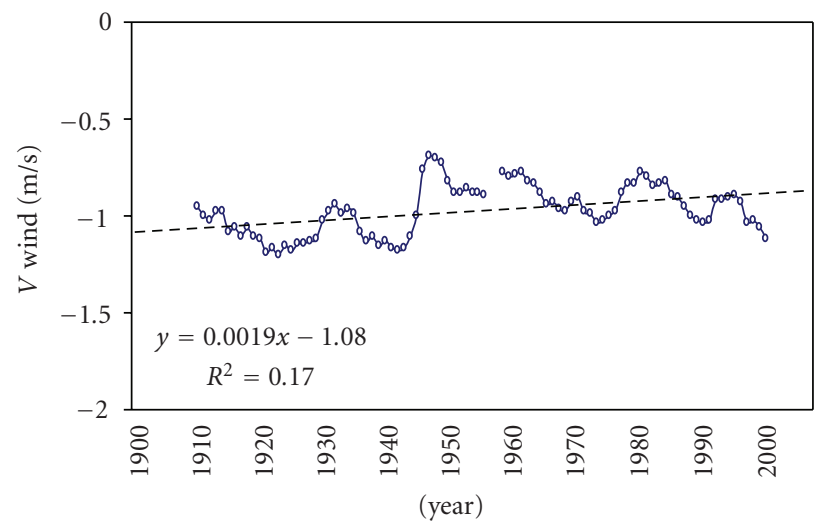

(d)

FIGURE 2: Caribbean area-averaged 5-yr smoothed time series for (a) SST and tropical cyclones, (b) SLP, (c) $U$ wind, and (d) $V$ wind. Trends and fit are given; units given on $Y$-axis.

errors contributed by uneven observations through spatial and temporal aggregation as outlined below.

To define the pattern and trend in the upper ocean, eigenvectors within a covariance matrix are calculated via the IRI Climate Library for each variable: $\mathrm{SSH}$, $T, S, U, V, W, \tau X, \tau Y$, from annual averages per grid cell and depth in the period 1958-2007. The leading principal component (mode-1) representing the dominant variability is analyzed as maps $\left(8^{\circ} \mathrm{N}-25^{\circ} \mathrm{N}, 85^{\circ} \mathrm{W}-55^{\circ} \mathrm{W}\right)$ using depth averages: $1-100 \mathrm{~m}$ for $T$ and $S$, and $1-200 \mathrm{~m}$ for $U, V, W$. This method is repeated for E-W depth sections $\left(85^{\circ} \mathrm{W}-55^{\circ} \mathrm{W}, 1-350 \mathrm{~m}\right.$, averaged over $\left.8^{\circ} \mathrm{N}-25^{\circ} \mathrm{N}\right)$ and N-S depth sections $\left(8^{\circ} \mathrm{N}-25^{\circ} \mathrm{N}, 1-350 \mathrm{~m}\right.$, averaged over $\left.85^{\circ} \mathrm{W}-55^{\circ} \mathrm{W}\right)$. In this manner, numerous profile observations are collapsed into each analysis.

Principal component (PC) analysis is employed as a way to cluster and deduce the long-term variability of concern here. Table 1 intercompares the variance explained by the first and second modes. The leading mode containing the trend, accounts for about half the variance in all fields except the ocean currents-where observations are potentially less reliable. Trends were found to be insignificant in secondary modes. To isolate the trend signal and establish the rate of
TABLE 1: Intercomparison of variance explained (\%) by the first and second PC modes.

\begin{tabular}{ccccccccc}
\hline & SSH & $T$ & $S$ & $U$ & $V$ & $W$ & $\tau X$ & $\tau Y$ \\
\hline 1 & 48 & 60 & 37 & 12 & 14 & 11 & 45 & 42 \\
2 & 11 & 7 & 11 & 9 & 6 & 5 & 17 & 20 \\
\hline
\end{tabular}

change, the slope of the mode-1 PC time score is mapped per grid cell. To determine its relative importance, the $r^{2}$ fit of the trend regression is calculated after standardizing and smoothing with a 5-yr running mean. Statistical significance is evaluated via the Pearson product-moment test with 10 degrees of freedom for sub-surface data $\left(r>|0.58| r^{2}>\right.$ 0.33 at $95 \%$ confidence) and 25 degrees of freedom for the longer surface records $\left(r>|0.38| r^{2}>0.14\right)$. Comparison of single-station long-term records is limited to SSH from Puerto Rico (1966+) and the Orinoco River discharge at $8^{\circ} \mathrm{N}, 63^{\circ} \mathrm{W}(1923+)$ and its catchment run-off from hydrological reanalysis [27].

Searching for long-term trends has certain pitfalls. Trends in upper ocean heat content are believed to have accelerated since the 1970s [3], and the sub-surface record 


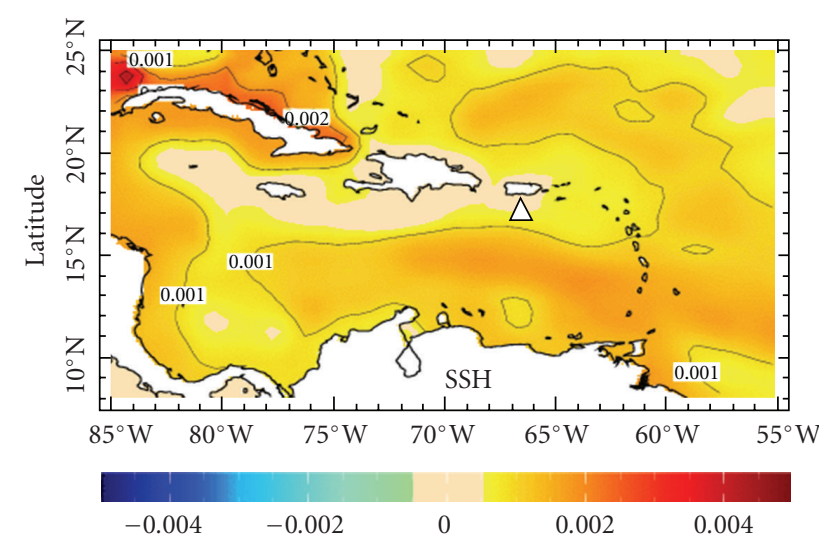

(a)

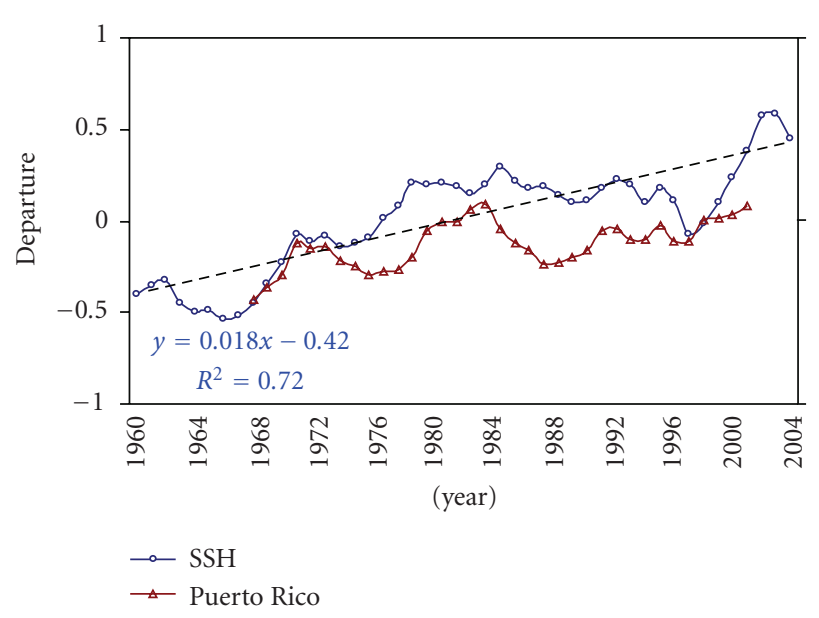

(c)

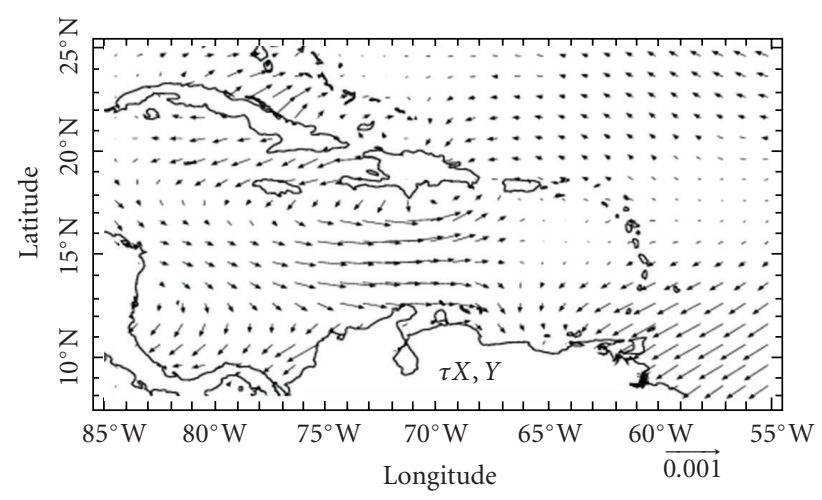

(b)

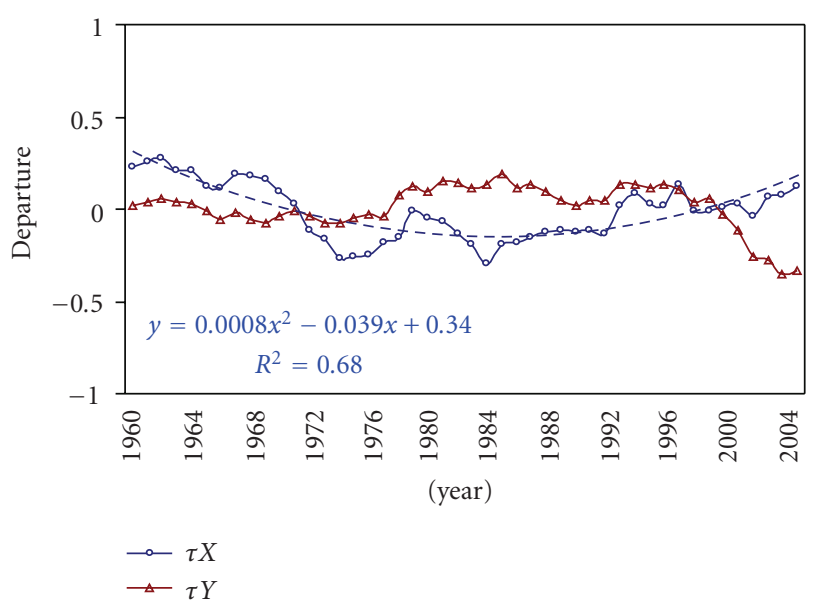

(d)

FIgURE 3: Rate of change per year for (a) sea surface height ( $\mathrm{m} / \mathrm{yr})$ and (b) wind stress $\left(\mathrm{N} \mathrm{m}^{-2} / \mathrm{yr}\right)$. (c) Smoothed standardized SSH time scores with Puerto Rico gauge (triangle in (a)) and trend. (d) Smoothed standardized wind stress time scores and trend. $Y$-axis is standardized departures in (c) and (d).

TABLE 2: Cross-correlation (\%) of mode-1 PC time score with linear trend, and with fish catch and crop yield lagged by 1 -year. Values above 58 are significant at the $95 \%$ confidence interval.

\begin{tabular}{lcccccccc}
\hline & SSH & $T$ & $S$ & $U$ & $V$ & $W$ & $\tau X$ & $\tau Y$ \\
\hline Trend & 85 & 83 & 83 & 81 & 83 & 81 & -26 & -19 \\
Fish & 26 & 28 & 27 & 11 & 16 & 15 & -6 & 38 \\
Crop & -16 & -26 & -27 & -37 & -39 & -39 & -10 & 7 \\
\hline
\end{tabular}

may reflect this signal. But the observational density changes with satellite data assimilated after 1979. Furthermore, the time series contain multidecadal oscillations that spread toward the Caribbean from higher latitudes (cf. SLP mode-1 pattern Figure 1(c); [28-30]). Using the wavelet co-variance technique of Torrence and Compo [31], it is seen that Caribbean SLP and SST share spectral energy around 16 years in the reanalysis era (Figure $1(\mathrm{~d})$ ). Thus, it is useful to distinguish trend from variability in the analysis. Ultimately, the results here should be considered "best estimates" with uncertainty contributed by instrument sampling errors and the interpolation of uneven observations to model grid-cells.

Biophysical relationships are analyzed by comparison of upper ocean PC scores with annual marine catch (including all species, $\sim 75 \%$ fish) for the Caribbean Sea, excluding Central and North American waters, obtained from the website http://www.fao.org/fishery/ in the reanalysis era. There are known reporting problems associated with the commercial exploitation of marine resources [32]; few countries have quality controlled historical catch data. For terrestrial resources, annual crop yields per (planted) area as an aggregate for all countries in the Caribbean (excluding Central and North America) were obtained from http://faostat.fao.org/ in the reanalysis era. Agricultural outputs display a step in 1985, so departures were computed from separate means. The sensitivity of crop yield (for avocado, coconut, citrus fruit, mango, spices, and sugar cane) was tested by comparison with upper ocean PC scores and with Caribbean area-averaged rainfall from the Global Precipitation Climatology Project [33]. Variability 


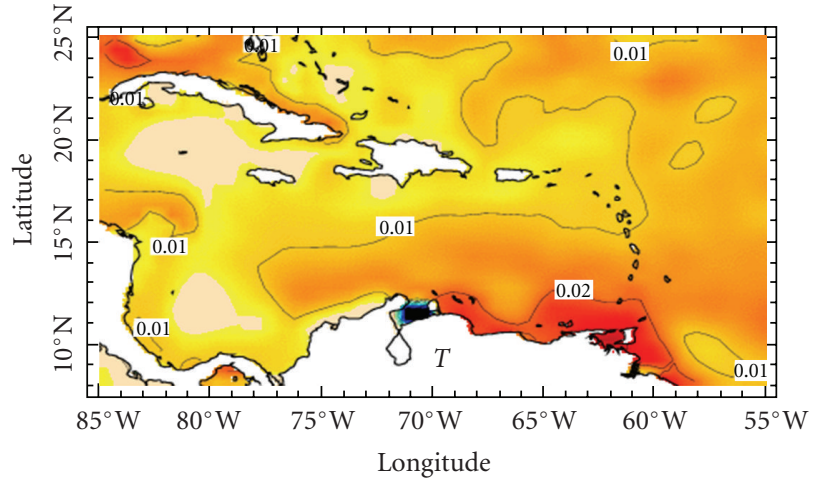

(a)

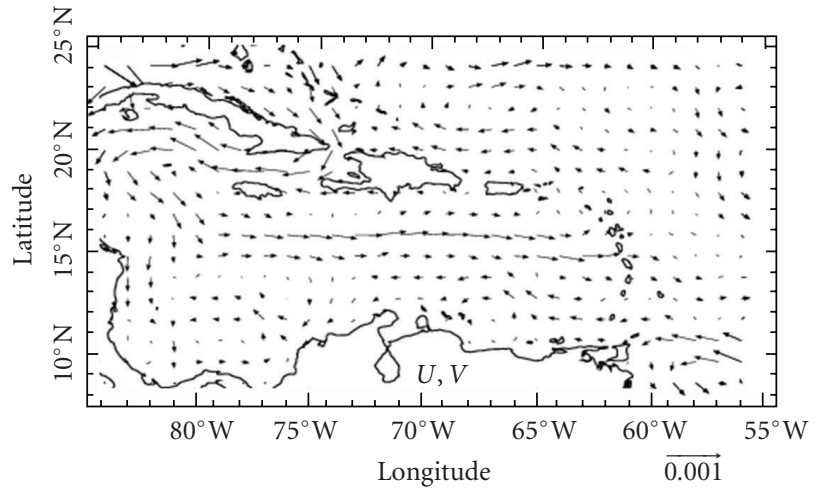

(c)

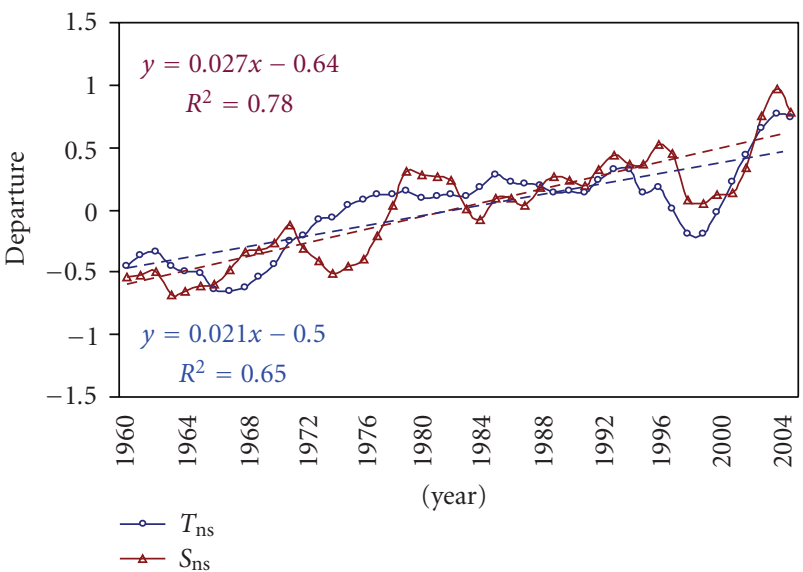

(e)

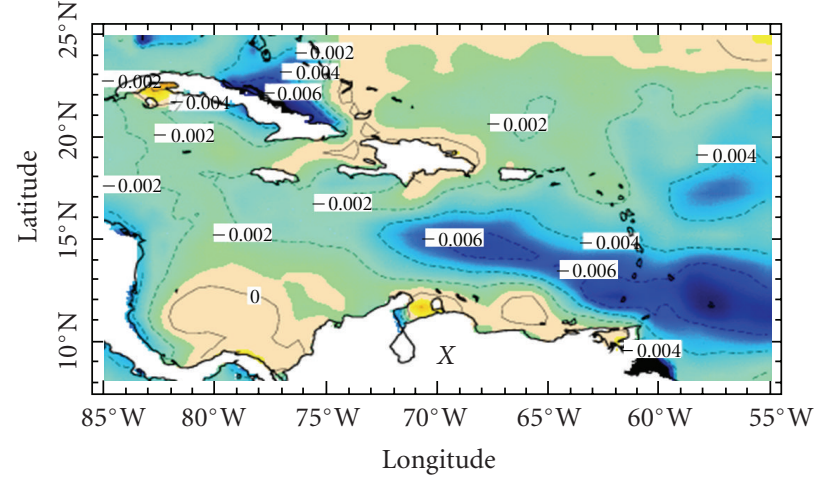

(b)

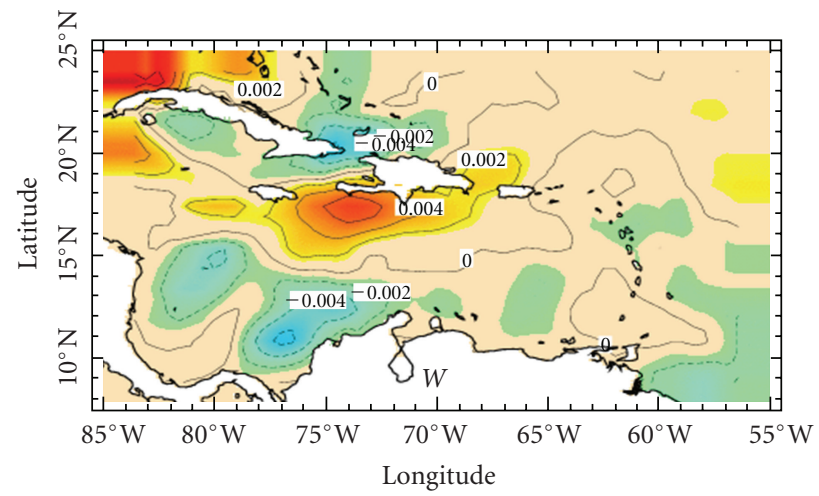

(d)

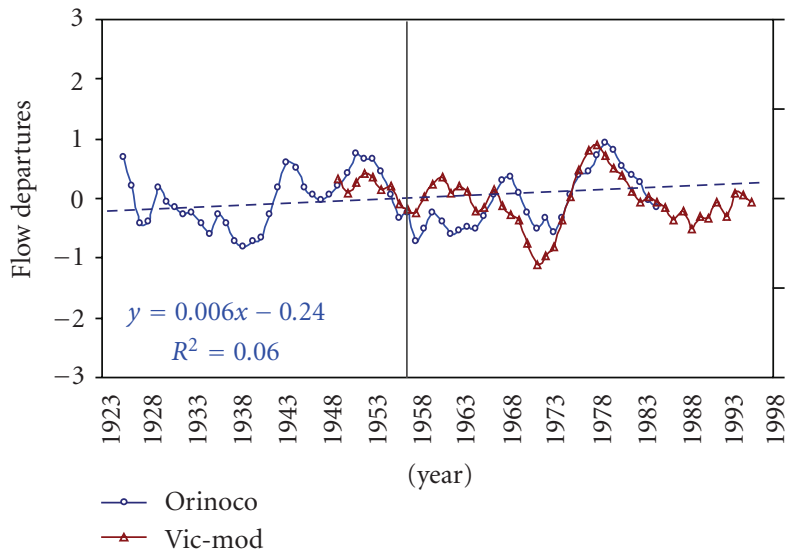

(f)

Figure 4: Rate of change per year for (a) temperature $\left({ }^{\circ} \mathrm{C} / \mathrm{yr}\right)$ and (b) salinity (ppt/yr) averaged 1-100 m. Rate of change for (c) currents as vectors with $\mathrm{m} / \mathrm{s}$ key, and (d) vertical motion ( $\mathrm{m} \mathrm{day}^{-1} / \mathrm{yr}$ ) averaged 1-200 $\mathrm{m}$. (e) $T$ and $S$ smoothed standardized time scores and trends, (f) 5 -yr smoothed Orinoco River gauge discharge (1923+) and trend, and catchment run-off from reanalysis (Vic-mod).

in resources may arise from environmental effects or from human influences such as changes in effort or reporting. With this in mind, the marine catch was divided by the Caribbean population. The marine catch per capita and crop yield time series are expected to integrate and lag climate, so cross-correlations were computed on annual resource indices at a 1-yr lag.

\section{Results}

3.1. Surface Trends. The historical Caribbean-area surface time series are given in Figure 2. SST exhibit quasi-decadal oscillations and a cool period in the early 20 th century. There is a positive second-order trend with $40 \%$ fit suggesting acceleration of warming in recent years. Tropical cyclones 


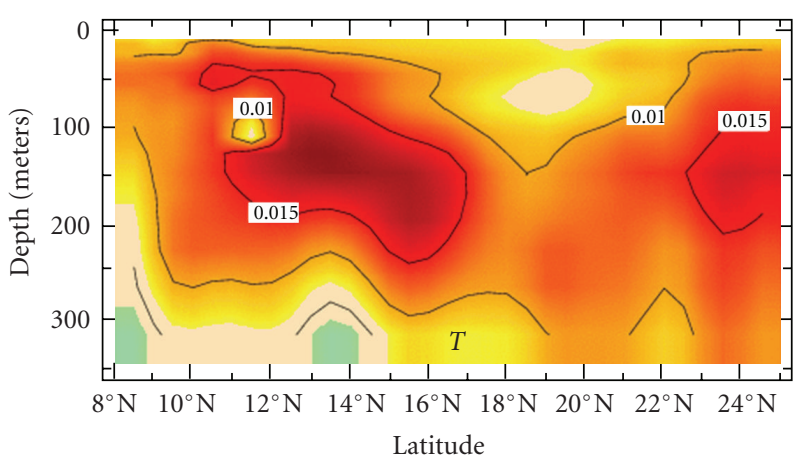

(a)

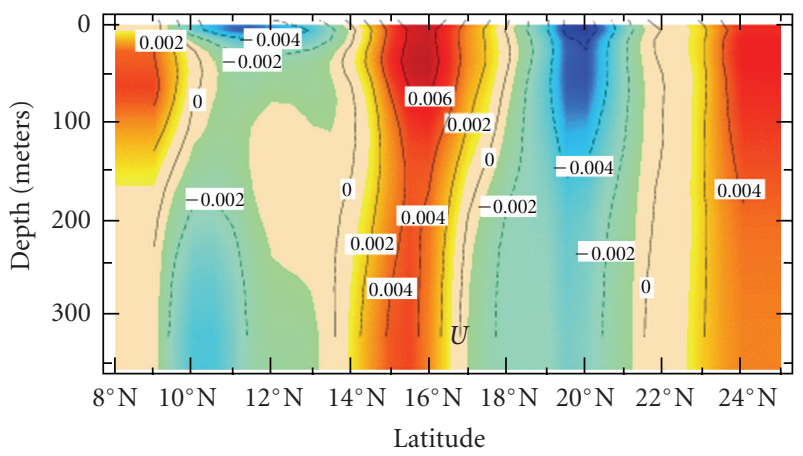

(c)

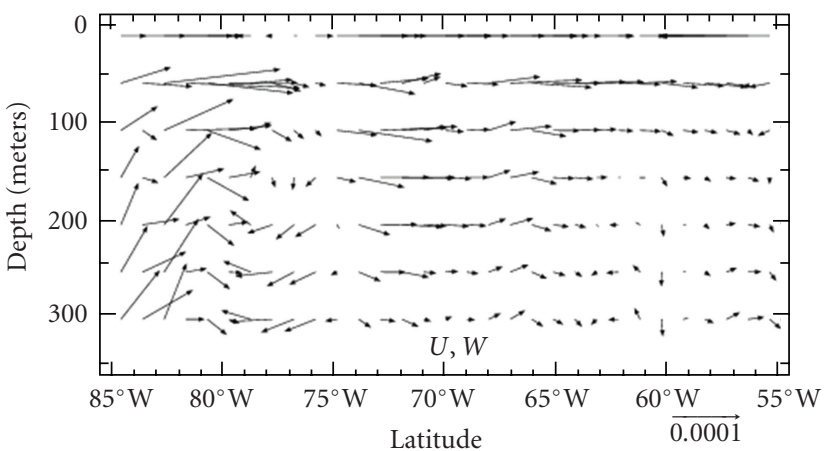

(e)

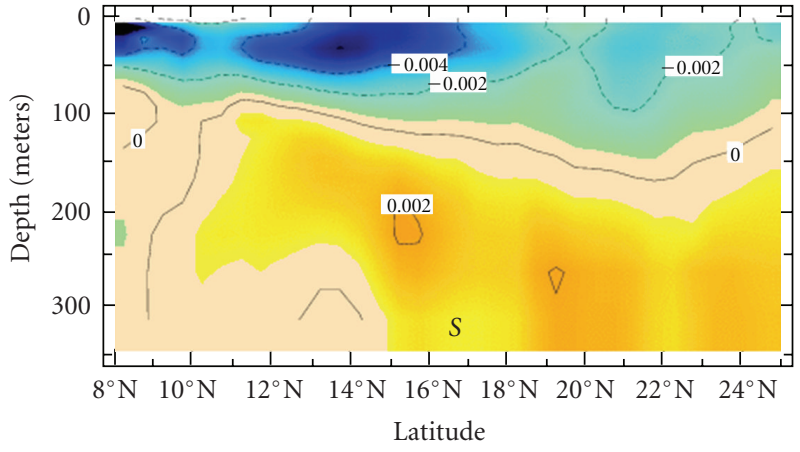

(b)

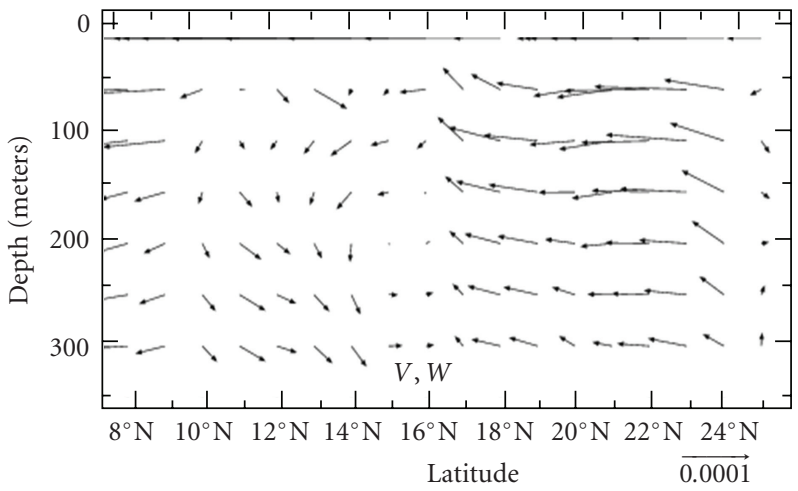

(d)

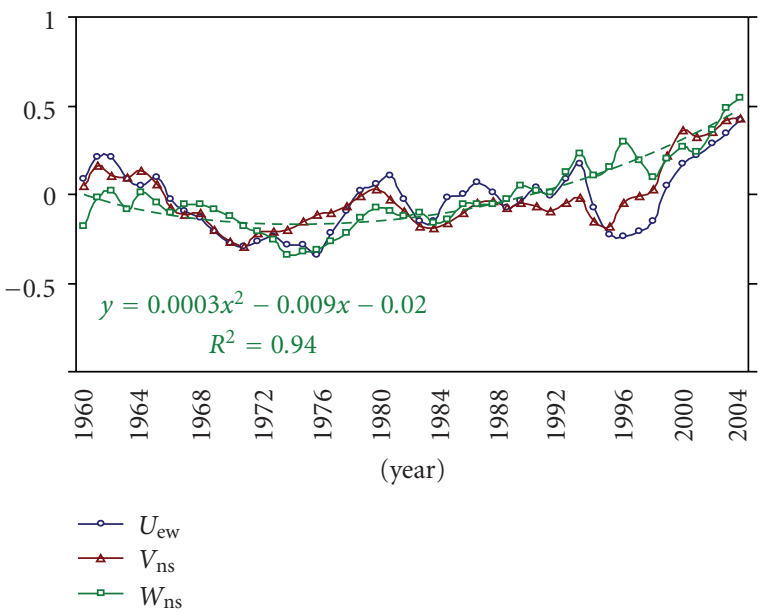

(f)

FIGURE 5: N-S sections of rate of change per year for (a) temperature, (b) salinity, (c) zonal current, and (d) meridional current and vertical motion as vectors with key. (e) E-W section of rate of change per year for zonal current and vertical motion as vectors with key. (f) $U, V, W$ smoothed standardized time scores and trend. $W$ exaggerated $10^{2}$ in $(\mathrm{d})$ and $(\mathrm{e})$.

in the Caribbean oscillate with SST but exhibit little trend. There is a widening gap (Figure 2(a)) induced by declining sensible heat fluxes $\left(T_{\text {air }}>\right.$ SST). SLP is inversely related to SST $(r=-0.66)$, with shared spectral energy in the bands $\sim 30$ and $\sim 60$ years before 1960 (cf. Figure 1(d)). SLP exhibits a weak downtrend and a 16-yr cycle since 1960 (Figure 2(b)). For surface wind, the reanalysis starts after 1900. Zonal wind has little trend over the 20th century while meridional wind exhibits a positive trend of $17 \%$ fit (Figures 2(c) and 2(d)).
The mode-1 loading pattern for reanalysis sea surface height (SSH; Figure 3(a)) is positive everywhere with higher values off Venezuela and around Cuba, and lower values along the central Antilles and Panama gyre. The faster rise in the vicinity of Key West/Havana relates to subsiding land. The SSH time score has a linear upward trend with $72 \%$ fit (Figure 3(c)). Station data for Puerto Rico indicate a slower rise of SSH than the regional mean. The wind stress "change vector" (from $U, V$ trends) is eastward in the central 


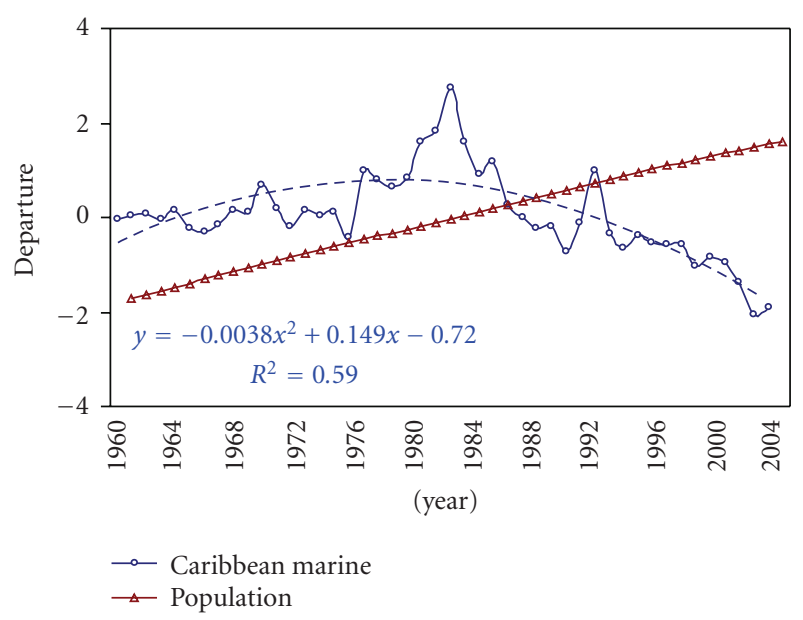

(a)

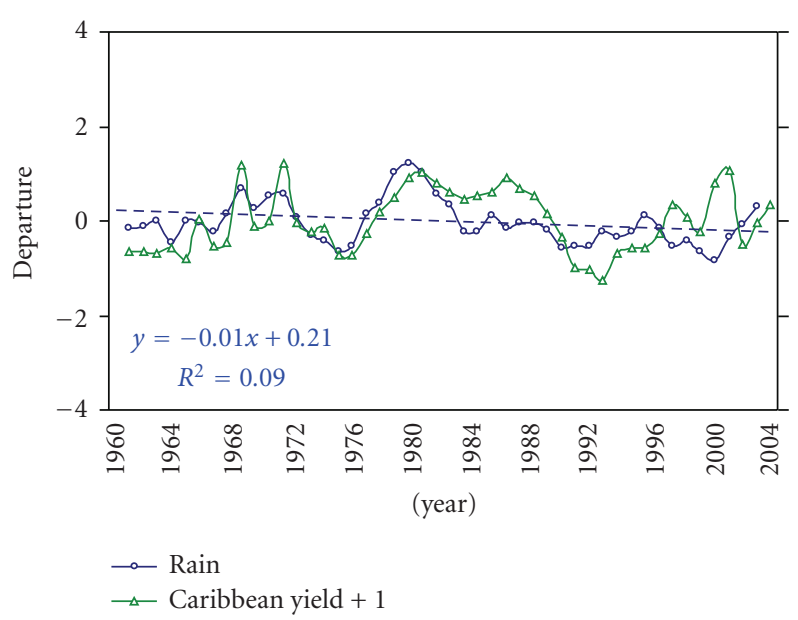

(b)

Figure 6: (a) Caribbean marine catch per capita and population growth. (b) Caribbean crop yield lagged by 1-yr and smoothed rainfall with trend.

Caribbean. South of Cuba and east of Trinidad NE trade winds have strengthened. The trend for $\tau X$ is second order with 68\% fit (Figure 3(d)).

3.2. Subsurface Maps. Maps of trends for T, S, currents, and $W$ are presented in Figure 4 . There has been widespread warming of the Caribbean thermocline layer as expected. The upward slope of $T$ is greatest off Venezuela (Figure 4(a)) associated with diminished trade wind upwelling in recent decades. Salinity in the thermocline has declined particularly in the Caribbean Current $13^{\circ}-17^{\circ} \mathrm{N}$, east of $75^{\circ} \mathrm{W}$ (Figure 4(b)). The fresh tongue suggests an influx of South Atlantic waters. Currents tend to loop around Jamaica from the Windward Passage and connect with eastward trends in the Caribbean Current (Figure 4(c)). The vertical motion trend is upward around Hispanola/Puerto Rico and sinking in the south off Colombia and Venezuela (Figure 4(d)).

Roemmich [12] found that surface and thermocline waters leaving the Caribbean through the Yucatan are composed of $17 \mathrm{~Sv}$ from the SE Caribbean and $6 \mathrm{~Sv}$ from the Windward Passage. What is seen in the trends here is a reduction of inflow from the SE Caribbean and an increase from the Windward Passage. There is a trend of reduced outflow toward the Yucatan. $T$ and $S$ linear trends achieve $65 \%$ and $78 \%$ fit, respectively (Figure 4(e)). Because salinity in the SE Caribbean is affected by the Orinoco plume [34], its discharge is considered (Figure 4(f)). The trend of river input over the historical record is weak, and regional rainfall is declining, so changes in ocean current advection underlie the freshening, not local air-sea fluxes.

3.3. Depth Sections. The temperature trend in N-S depth section (Figure $5(\mathrm{a})$ ) exhibits a maximum from $11^{\circ}-16^{\circ} \mathrm{N}$ at 100-200 m depths. The amplitude of warming is weakest at the surface and in the south below $300 \mathrm{~m}$. The salinity depth section (Figure 5(b)) exhibits negative (positive) loading above (below) $\sim 150 \mathrm{~m}$, hence the halocline has weakened.
This interface slopes downward to the north with greatest freshening from $12^{\circ}-17^{\circ} \mathrm{N}$ above $50 \mathrm{~m}$. The N-S depth section for zonal currents is given in Figure 5(c). Alternating bands are evident; the maximum eastward trend is near $15^{\circ} \mathrm{N}$ in the Caribbean Current. The rate of change for currents expressed as vectors in depth sections is southeastward. For the N-S section of $V$ current (Figure 5(d)) trends are greatest from $18-23^{\circ} \mathrm{N}$ above $300 \mathrm{~m}$ reflecting inflow from the Antilles Current. Vertical components are largely upward (downward) north (south) of $15^{\circ} \mathrm{N}$, reflecting a trend toward rising (sinking) motions in the central Antilles (off South America). Weaker upwelling in the southern Caribbean relates to a weakening of trade winds since 1990 (cf. Figure 3(b)). The $U$ current trend is generally eastward over the Nicaragua Rise and in the central Caribbean $75^{\circ}-60^{\circ} \mathrm{W}$ above $200 \mathrm{~m}$ (Figure 5(e)). Trends and slow fluctuations of the Caribbean thermocline circulation appear modulated by inflow from Grenada $(U)$ and Windward $(V)$ Passages. The time series for currents has a positive second-order trend with 94\% fit (Figure 5(f)). Multidecadal oscillations appear to influence the circulation (second-order trends) more than thermodynamic properties (linear) in the reanalysis era.

3.4. Resources. The marine catch per capita is relatively stationary in the 1960s (Figure 6(a)) and rises in the 1980s as tropical cyclones decline (cf. Figure 2(a)). Thereafter, catch becomes depleted, with a negative second-order trend of $59 \%$ fit. Population growth follows global trends, doubling in the reanalysis era and stressing resources. Caribbean crop yield followed rainfall until recently; a weak drying trend is noted (Figure 6(b)). Crop yield is less sensitive to upper ocean conditions; cross-correlations at 1-yr lag are generally negative with declining yields and moderate with respect to ocean currents (cf. Table 2 ).

Table 2 summarizes the PC score mode-1 crosscorrelations with linear trend. Upward, significant values are seen for all variables except wind stress. Thus, global 
warming signals (and reduced dS/dz) emerge from the analysis. Cross-correlations between environmental PC scores and marine fish catch lagged by 1-year are also summarized in Table 2. Surprisingly, the values are insignificant, suggesting that patterns of advection and thermodynamic properties may be less important than factors affecting catch effort and efficiency (e.g., storm frequency, sea state). The moderate correlation with $\tau Y$ suggests that increased catch follows northward winds originating from the Venezuela upwelling zone.

\section{Summary}

Conditions in the Caribbean Sea have been studied for longterm trends in the period of historical surface observations using area-averages and in sub-surface fields using principal component analysis and trend extraction. Continuous data coverage started in the 1850s for SLP and SST, the 1900s for winds, and in the late 1950s for model reanalyzed sea surface height and sub-surface $T, S$, currents and vertical motion. Data aggregation methodologies were employed to reduce variability in time, space, and depth, leaving the longterm trend which was analyzed by regression to first or second order. SST reflected an accelerating upward trend while SLP exhibited quasi-decadal fluctuations. SSH and sub-surface $T$ rose linearly at near-global rates while subsurface $S$ exhibited fresher upper and saltier lower layers. The amplitude of warming was spatially homogeneous but weak in the upper $100 \mathrm{~m}$, so the top-down hypothesis related to air-sea exchange was unsupported. Averaged over the Caribbean, temperatures have risen at twice the rate $(.015 \mathrm{C} / \mathrm{yr})$ at $150 \mathrm{~m}$ than in other layers. Sea surface height trends were found to be highest $(+.0014 \mathrm{~m} / \mathrm{yr})$ at $14^{\circ}$ and $23^{\circ} \mathrm{N}$ and lower $(+.0008 \mathrm{~m} / \mathrm{yr})$ at $10^{\circ}$ and $18^{\circ} \mathrm{N}$. Freshening of the surface layer was unrelated to regional rainfall or river discharge, suggesting changes in ocean advection and sources. Salinity has declined fastest $(-.004 \mathrm{ppt} / \mathrm{yr})$ near $30 \mathrm{~m}$. Crop yields were insensitive to ocean conditions, and followed rainfall as expected. Marine catch per capita in the Caribbean was unrelated to $T$ and $S$, and followed enhanced northward winds that spread productivity.

The Caribbean Sea has experienced a rate of climate change that is faster than most other coral reef zones of the world according to a recent study [35]. This is a cause for concern-given declining food resources, receding beaches, and the dependence of local economies on coastal tourism.

\section{References}

[1] M. R. Jury and A. Winter, "Warming of an elevated layer over the Caribbean," Climatic Change, pp. 1-13, 2009.

[2] IPCC, "Physical Science Basis, 4th Assessment Report of the Intergovernmental Panel on Climate Change," Cambridge University Press, New York, NY, USA, 996 pages, 2007.

[3] C. M. Domingues, J. A. Church, N. J. White et al., "Improved estimates of upper-ocean warming and multi-decadal sea-level rise," Nature, vol. 453, no. 7198, pp. 1090-1093, 2008.

[4] J. Nyberg, B. A. Malmgren, A. Winter, M. R. Jury, K. H. Kilbourne, and T. M. Quinn, "Low Atlantic hurricane activity in the 1970 s and 1980 s compared to the past 270 years," Nature, vol. 447, no. 7145, pp. 698-701, 2007.

[5] S. J. Murphy, H. E. Hurlburt, and J. J. O’Brien, “The connectivity of eddy variability in the Caribbean Sea, the Gulf of Mexico, and the Atlantic Ocean," Journal of Geophysical Research C, vol. 104, no. 1, pp. 1431-1453, 1999.

[6] C. A. Andrade and E. D. Barton, "Eddy development and motion in the Caribbean Sea," Journal of Geophysical Research C, vol. 105, no. 11, pp. 26191-26201, 2000.

[7] W. E. Johns, T. L. Townsend, D. M. Fratantoni, and W. D. Wilson, "On the Atlantic inflow to the Caribbean Sea," DeepSea Research I, vol. 49, no. 2, pp. 211-243, 2002.

[8] J. Gyory, A. J. Mariano, and E. H. Ryan, "The Caribbean Current' Ocean Surface Currents," 2005, http://oceancurrents .rsmas.miami.edu/caribbean/caribbean.html.

[9] R. L. Molinari, M. Spillane, I. Brooks, D. Atwood, and C. Duckett, "Surface current in the Caribbean Sea as deduced from Lagrangian observations," Journal of Geophysical Research, vol. 86, pp. 6537-6542, 1981.

[10] T. H. Kinder, G. W. Heburn, and A. W. Green, "Some aspects of the Caribbean circulation," Marine Geology, vol. 68, no. 1-4, pp. 25-52, 1985.

[11] D. M. Fratantoni, "North Atlantic surface circulation during the 1990's observed with satellite-tracked drifters," Journal of Geophysical Research C, vol. 106, no. 10, pp. 22067-22093, 2001.

[12] D. Roemmich, "Circulation in the Caribbean Sea: a resolved inverse problem," Journal of Geophysical Research, vol. 86, pp. 7993-8005, 1981.

[13] A. Hernandez-Guerra and T. M. Joyce, "Water masses and circulation in the surface layers of the Caribbean at $66^{\circ} \mathrm{W}$," Geophysical Research Letters, vol. 27, no. 21, pp. 3497-3500, 2000.

[14] J. T. Gunn and D. R. Watts, "On the currents and water masses north of the Antilles/Bahamas Arc," Journal of Marine Research, vol. 40, no. 1, pp. 1-48, 1982.

[15] T. N. Lee, W. E. Johns, R. J. Zantopp, and E. R. Fillenbaum, "Moored observations of western boundary current variability and thermohaline circulation at $26.5^{\circ} \mathrm{N}$ in the subtropical North Atlantic," Journal of Physical Oceanography, vol. 26, no. 6, pp. 962-983, 1996.

[16] W. J. Schmitz and P. L. Richardson, "On the sources of the Florida current,” Deep-Sea Research, vol. 38, pp. 379-409, 1991.

[17] W. D. Wilson and W. E. Johns, "Velocity structure and transport in the Windward Islands passages," Deep-Sea Research I, vol. 44, no. 3, pp. 487-520, 1997.

[18] R. C. Wajsowicz, "A modified sverdrup model of the Atlantic and Carribbean circulation," Journal of Physical Oceanography, vol. 32, no. 3, pp. 973-993, 2002.

[19] A. Alvera-Azcárate, A. Barth, and R. H. Weisberg, "The surface circulation of the Caribbean Sea and the Gulf of Mexico as inferred from satellite altimetry," Journal of Physical Oceanography, vol. 39, no. 3, pp. 640-657, 2009.

[20] T. M. Smith, R. W. Reynolds, T. C. Peterson, and J. Lawrimore, "Improvements to NOAA's historical merged land-ocean surface temperature analysis (1880-2006)," Journal of Climate, vol. 21, no. 10, pp. 2283-2296, 2008.

[21] J. S. Whitaker, G. P. Compo, X. Wei, and T. M. Hamill, "Reanalysis without radiosondes using ensemble data assimilation," Monthly Weather Review, vol. 132, no. 5, pp. 11901200, 2004.

[22] G. P. Compo, J. S. Whitaker, and P. D. Sardeshmukh, "Feasibility of a 100-year reanalysis using only surface pressure 
data," Bulletin of the American Meteorological Society, vol. 87, no. 2, pp. 175-190, 2006.

[23] R. Allan and T. Ansell, "A new globally complete monthly historical gridded mean sea level pressure dataset (HadSLP2): 1850-2004," Journal of Climate, vol. 19, no. 22, pp. 5816-5842, 2006.

[24] K. Emanuel, "A statistical analysis of tropical cyclone intensity," Monthly Weather Review, vol. 128, no. 4, pp. 1139-1152, 2000.

[25] J. A. Carton and B. S. Giese, "A reanalysis of ocean climate using Simple Ocean Data Assimilation (SODA)," Monthly Weather Review, vol. 136, no. 8, pp. 2999-3017, 2008.

[26] S. M. Uppala, P. W. Kållberg, A. J. Simmons et al., "The ERA40 re-analysis," Quarterly Journal of the Royal Meteorological Society, vol. 131, no. 612, pp. 2961-3012, 2005.

[27] J. Sheffield, G. Goteti, and E. F. Wood, "Development of a 50year high-resolution global dataset of meteorological forcings for land surface modeling," Journal of Climate, vol. 19, no. 13, pp. 3088-3111, 2006.

[28] N. J. Mantua, S. R. Hare, Y. Zhang, J. M. Wallace, and R. C. Francis, "A Pacific interdecadal climate oscillation with impacts on salmon production," Bulletin of the American Meteorological Society, vol. 78, no. 6, pp. 1069-1079, 1997.

[29] D. B. Enfield, A. M. Mestas-Nuñez, and P. J. Trimble, "The Atlantic multidecadal oscillation and its relation to rainfall and river flows in the continental U.S," Geophysical Research Letters, vol. 28, no. 10, pp. 2077-2080, 2001.

[30] D. E. Harrison and M. Carson, "Is the world ocean warming? Upper-ocean temperature trends: 1950-2000," Journal of Physical Oceanography, vol. 37, no. 2, pp. 174-187, 2007.

[31] C. Torrence and G. P. Compo, "A practical guide to wavelet analysis," Bulletin of the American Meteorological Society, vol. 79, no. 1, pp. 61-78, 1998.

[32] FAO (Food and Agriculture Organization of the United Nations), "Marine fishery resources of the Antilles: Lesser Antilles, Puerto Rico and Hispaniola, Jamaica, Cuba," FAO Fisheries Technical Paper 326, 1993.

[33] U. Schneider, T. Fuchs, A. Meyer-Christoffer, and B. Rudolf, "Global precipitation analysis products of the GPCC," DWD, WCRP Technical Publication, Global Precipitation Climatology Centre, 2008.

[34] A. Ffield, "Amazon and Orinoco River plumes and NBC rings: bystanders or participants in hurricane events?" Journal of Climate, vol. 20, no. 2, pp. 316-333, 2007.

[35] M. R. Jury, S. Heron, C. Spillman, and K. Anthony, "Climate, Carbon and Coral Reefs, World Meteorological Organization technical report 1063," Geneva, Switzerland, 2010, http://www.wmo.int/pages/prog/wcp/agm/publications/documents/Climate_Carbon_CoralReefs.pdf. 

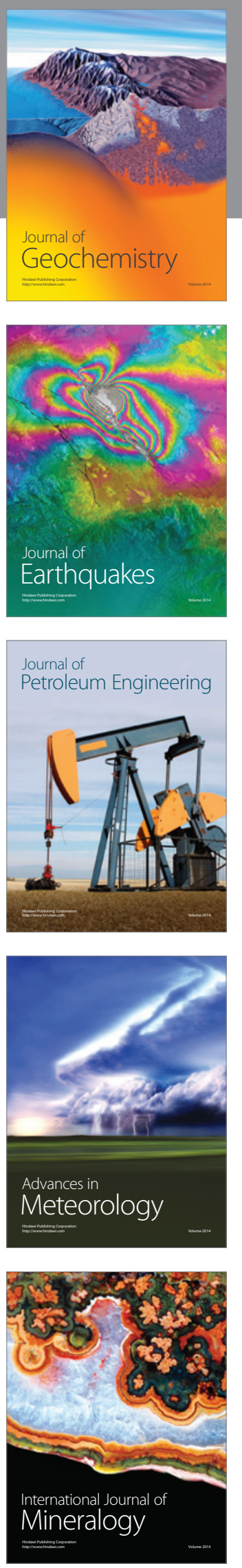
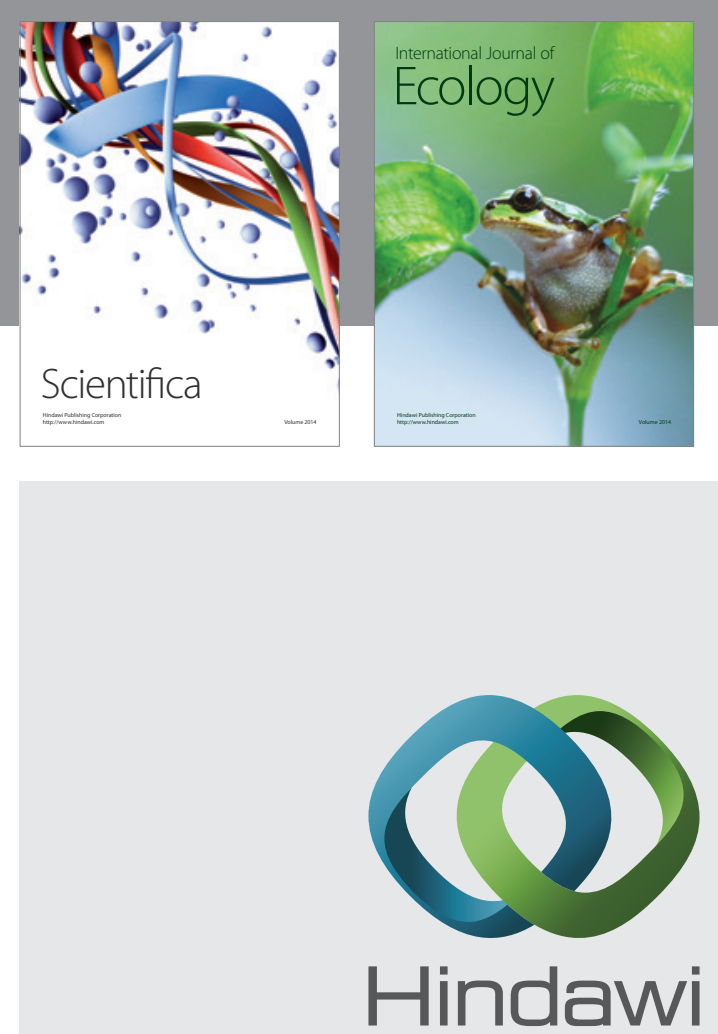

Submit your manuscripts at http://www.hindawi.com
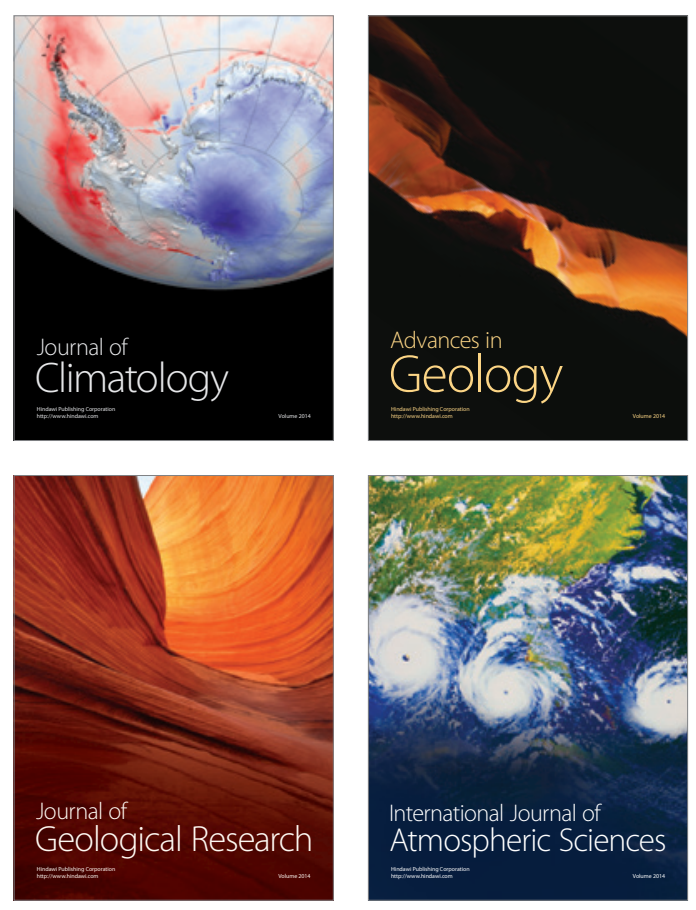
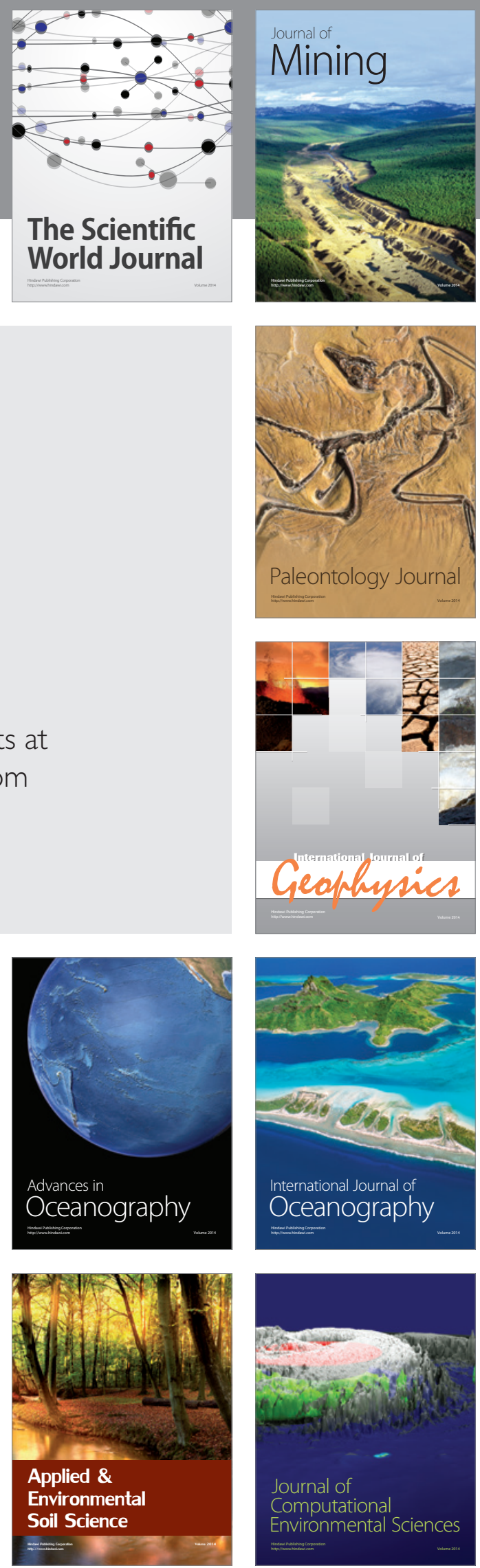